\title{
Status of Mountain Pastures, Including Geobotanical Description of the Main Vegetation Associations in Western Pamir-Alay
}

\author{
Mukaddas B. Tirkasheva \\ Djizak Polytechnical Institute, Djizak, Uzbekistan \\ Email: ozodbek88@bk.ru
}

How to cite this paper: Tirkasheva, M.B. (2019) Status of Mountain Pastures, Including Geobotanical Description of the Main Vegetation Associations in Western Pamir-Alay. American Journal of Plant Sciences, 10, 1689-1698.

https://doi.org/10.4236/ajps.2019.1010120

Received: August 2, 2019

Accepted: October 5, 2019

Published: October 8, 2019

Copyright $\odot 2019$ by author(s) and Scientific Research Publishing Inc. This work is licensed under the Creative Commons Attribution International License (CC BY 4.0).

http://creativecommons.org/licenses/by/4.0/

\begin{abstract}
The article gives a brief description of the vegetation cover of the Western Pamir-Alai range, as well as a method of describing the phytocenosis of the vegetation of the studied region.
\end{abstract}

\section{Keywords}

Western Pamir-Alai, Pastures, Phytocenosis, Formation, Association, Flora

\section{Introduction}

The studied region is one of the most interesting regions of Uzbekistan, characterized by a kind of floristic richness and a high percentage of endemic species. A large variety of trees and shrubs and herbaceous plants is concentrated here, much of which is of high value for the national economy. In order to preserve the diversity of vegetation and maintain them in a sustainable productive state, knowledge of the patterns and characteristics of the formation, spatial distribution of vegetation and their communities, their current state, trends and rationing of natural plant resources are of particular relevance.

\section{Material and Methods}

As a result of the analysis of generally accepted and modern methods for the implementation of goals and objectives for the study of the state of mountain pastures it is recommended to use the following methods:

- Itinerary reconnaissance studies. When they were carried out, it was supposed to give the most general geobotanical characteristic of the vegetation cover of the surveyed territory. In this case, the most important, the most 
common formations and their connections with the relief of soil conditions should be characterized in general terms. The spatial distribution of the main formations is given in the description of large geobotanical regions, which are also outlined only tentatively [1] [2].

- Reconnaissance studies are usually carried out with the purpose of the primary or a specific region. Their task is the general qualitative characteristic of vegetation on the basis of taking into account local peculiarities of its formation and placement. As a result, materials characterizing the main features of the vegetation cover are obtained, areas differing in geobotanical terms are allocated, the most important forest, pasture, meadow and other funds are identified for further development, and forecasts of land use are outlined. These data open up the possibility of scientifically based planning and zoning of certain economic important measures.

\section{Methods for the Description of Phytocenoses}

When describing vegetation cover, it is necessary to indicate the conditions of its formation: geological features, geographical location of the studied area, its climatic conditions. The description process includes floristic composition, total number, weight of plants and quantitative relationships between species and groups of species, the condition of individuals of each species ("vitality"), spatial-vertical and horizontal-distribution of plants and structural parts of the phytocenosis.

\section{Result and Discussion}

As a result of the analysis of literature sources and on the basis of common experience, it was found that the phytocenotic diversity of mountain pasture vegetation cover consists of 3 types, 4 subtypes, 7 cenotypes, 8 formations and 27 associations.

To test this methodology and obtain primary data, we carried out two expeditions together:

The first route passes through the territory of the forestry of the Yakkabag region. The second route passes through the territory of the Gissar reserve Miraki area of Kashkadarya region.

According to the results of work in the study area (Yakkabag forestry and Gissar reserve, Miraki site) the following plant species are endemic: Acantholimon butkovii L i p with z. (Khorasan-mountain-Middle Asian community), Cousinia allolepis Tschern. et Vved. (Iran-Central Asian community), C. bobrovii J u z. (Southern Pamir-Alai community), C. hoplophylla Tschern (Pamiro-Alay community), Oxytropis vvedenskyi Filim, (high mountain community Asia O. savellanica Bg), Tanacetopsis botschantzevii Kovalevski (Pamiro-Alay community). According to the references, as well as, when fixing in this study area, there are several plant species listed in the Red Book of Uzbekistan: Astragalus butkovii Popov, A. komarovii Lipsky, Cicir incanum Korotkova, Oxytropis 
tyttantha Gontsch, Ferula sumbul Kauffm.

The region we are studying is located in high-altitude areas, mainly in the zone of adyrs, in the middle mountains and in the highlands, each of which has its own landscape components. When classifying the phytocenoses of the studied areas, the classification of P. K Zakirov [2] [3] [4] [5] was adopted.

Type: Hill-Imioreophyton (Adyrophyton) Hill-alpine;

Coenotype: Herbal ephemeroids-Ephemeroidopoia;

Formation: Bluegrass-Poaeta bulbosae.

\section{Associations:}

1) Bluegrass-sedge-grass (Poa bulbosa, Carex pachystylis, Phlomoides labiosa, Hypericum elongatum), area $10 \times 10 \mathrm{~m}$. The soil is mixed with simple gray, small pale earth. Plant coverage is 60\% - 65\%: Edifier Poa bulosa, Cop ${ }^{2}$ abundance, non-specific Carex pachystylis, $\mathrm{Sp}^{3}$ abundance. They constitute the lower part of the vegetation cover. Their height is $15-20 \mathrm{~cm}$.

2) Bluegrass-fenugs-forbs (Poa bulbosa, Trigonella grandiflora, Achillea millefolium, Cousinia microcarpa). The area is $10 \times 10 \mathrm{~m}$. The soil is small, soft, and some parts of the soil are dark. Plants of this type in the community account for $70 \%-75 \%$ of the total. Bluegrass edificator, Cop $^{2}$ abundance, Trigonella grandiflora subedifier, $\mathrm{Sp}^{3}$ abundance constitute the lower half of the vegetation cover $(20-25 \mathrm{~cm})$. Herbs Cousinia microcarpa, Ixiolirion tataricum, Galium verum, Achillea millefolium, which height is $35-40 \mathrm{~cm}$, make up the upper tier. These two associations met in Yakkabag forestry at an altitude of $1500 \mathrm{~m}$ above sea level.

Formation: Perovskieta scrophularifoliae.

The semi-shrub plant belongs to the Lamiaceae Lindl family.

\section{Associations:}

3) Panicle grassy grass (Perovskia scrophularifolia, Cynodon dactylon, Poa bulbosa, Elytrigia repens, Eryngium macrocalyx, Achillea millefolium). Communities are common on dark gray soils, where there is a little grass on the surface. The prevalence of Perovskia-scrophularifolia edificator is $\mathrm{Cop}^{2}$, Sub-equalizers $C y$ nodon dactylon, abundance of Sp3, Poa bulbosa $\mathrm{Sp}^{3}$, Elytrigia trychophora $\mathrm{Sp}^{3}$. Erigeron macrocalyx, Alhagi psevdoalhagi, Plantago lanceolata, Achillea millefolium and others, participate in this association. Their abundance is $\mathrm{Sp}^{1}$, but on the field there are many ephemeral, ephemeroid, Sol-Sp${ }^{1}$. This association was found in Yakkabag forestry in 1 site at an altitude of $2100-2200 \mathrm{~m}$ above sea level.

Formation: Hairy wheat grass-Elytrigieta trichophorae.

As a result of our research in the Hissar ranges, the following 5 associations of wheatgrass flora were found at an altitude of $1800-1900 \mathrm{~m}$ above sea level, and in rare cases up to $2000 \mathrm{~m}$ above sea level.

\section{Associations:}

4) Misting grass (Phlomis olgae, Haplophyllum perforatum) association, in the foothills of the Gissar mountains, distributed at an altitude of $1700-1800 \mathrm{~m}$ above sea level. Its fields are in the range of grain fields and are used as "grass". 
The soil is dark gray, small, soft, rich in humus. Vegetable coverage is $80 \%$ $90 \%$. Elythrigia trichophora participates in the community, which accounts for $60 \%$ of the total vegetation cover. The vegetation cover of this community is Cop2, height $60-70 \mathrm{~cm}$. Subdefinators are Haplophyllum perforatum and Phlomis olgae, and their abundance is $\mathrm{Sp}^{2}-\mathrm{Sp}^{3}$. Hordeum bulbosum, H. leporinum are also found.

5) Forbs and mixed shrubs-wheatgrass (Elytrigia trichophora, Rosa maracandica, Cerasus erythrocarpa, Amygdalus spinosissima, Lonicera altmannii, Ferula kokanica, Daucus carota). This is an association 2.5 - $3 \mathrm{~km}$ south of the village of Suvlisay). The area is $10 \times 10 \mathrm{~m}$. The height is $1900 \mathrm{~m}$ above sea level, the vegetative cover of the community is $45 \%$. The edificator is Elytrigia trichophora, Cop ${ }^{1}$ abundance, Rosa maracandica, Cerasus erythrocarpa, Lonicera altmanii abundance $\mathrm{Sp}^{2}$ abundance. Herbal blend Ferula kuhistanica, Daucus carota $\mathrm{Sp}^{1}$. Stones are thrown from places where the soil is covered with dark soil. In such places grow shrubs.

6) Forbs-grass-grass-prairie (Elytrigia trichophora, Poa bulbosa, Scabiosa songorica, Phlomis olgae) were recorded in Yakkabag forestry. This association is located at an altitude of 1800 meters above sea level. The soil is light brown, carbonate, the surface is sufficiently washed. In the community, vegetation cover is $60 \%$, Pyrei, Cop ${ }^{2}$, height $40-50 \mathrm{~cm}$. Sub grass fertilizer Cop ${ }^{1}$ abundance, height $25-30$ $\mathrm{cm}$. Scabiosa songorica, Phlomis olgae abundance of $\mathrm{Sp}^{1}$ and also astragalus Sol abundant, 35 - 40 in height. See Community represented on two tiers.

7) Herb-grass-eremuros-wheatgrass (Elytrigia trichophora, Eremurus olgae, Poa bulbosa, Cousinia microcarpa, Phlomis salicifolia). This association is common at an altitude of $1900 \mathrm{~m}$. Plot $10 \times 10$ is a dark gray soil, fine, some places are cartilaginous. Plants cover 55\% - 60\%. Edificator Elytrigia trichophora, height $40-45 \mathrm{~cm}$, the abundance of Cop ${ }^{2}$. Subedifiers Poa bulbosa and Eremurus Olgae, their abundance Sp3 Cop ${ }^{1}$. Herb height is $25-30 \mathrm{~cm}$, and Eremurus is $30-40 \mathrm{~cm}$. From the herb Cousinia microcarpa, Alhaghi pseudalhagi, Tarxacum officinalis and from the shrubs Artemisia tenuisecta. The community of plants consists of 2 tiers. The upper tier is the Bluegrass, Eremurus, and in the lower tier there are grasses, dandelion and field bindweed.

8) Herb-fescue-couch grass (Elytrigia trichophora, Festuca valesiaca, Phlomis salicifolia, Centaurea squarrosa). This association was recorded in two areas studied at an altitude of $1700-2000 \mathrm{~m}$ and more. $\mathrm{m}$., The area is $10 \times 10 \mathrm{~m}$, the soil is dark gray, fine, on the surface is rocky and small gravel stones, the plant coverage is $65 \%-70 \%$. The edificator is Elytrigia trichophora; it grows evenly on the square, Cop $^{2}$ abundance, $45 \mathrm{~cm}$ high. Festuca valesiaca subedifier, its height is $20-25 \mathrm{~cm}$, Cop ${ }^{1}$ abundance, cereal $25-30 \mathrm{~cm}$ high. $\mathrm{Sp}^{1}$. On the square, both species are distributed evenly and form the lower tier of the vegetation of this association. Of the mixed herbs are represented by a white-leaved, zopnik, eremurus Olga, which form the upper tier. It is in this tier Samarkand rosehip, is rare. This association can be found on the Gissar ridge, $10 \mathrm{~km}$ from the village of 
Tamshush, at an altitude of 2000 and more meters above sea level. The soil is light brown, fine, soft. Vegetation cover, 75\% - 80\%, and cereals make up 55\% $60 \%$, the upper tier with an abundance of $\mathrm{Cop}^{3}, 50-60 \mathrm{~cm}$ high. Tipchak is a subedificator, with an abundance of Cop1, $30 \mathrm{~cm}$ high. From the raznotravya met Carex pachystylis, Phlomis salicifolia, Cichorium intybus, Heteropappus canescens and others.

\section{Vegetation of the middle mountains}

Type: Plants of middle mountains (Oriofil)_Medioriophyton (Oreophyton);

Subtype: Oreomesophilic plants-Oreomesophyta;

Cenotype: Mesophilic shrubs-Oritherothamna;

Formation: Mixed Bearing-Rosarieta (Therothamna).

Mountain vegetation cover is located in Yakkabag forestry, as well as $3-5 \mathrm{~km}$ from the village of Tamshush. From 1500 to $1600 \mathrm{~m}$ to $2000-2700 \mathrm{~m}$ above sea level, there are many rubbing stony and cobblestone areas on the southern slopes, and therefore plant communities are diverse. Mesophilic plant communities contain 2 prices and 3 formations (Figure 1).

\section{Associations:}

9) Motley grass mixed spines (Rosa kokanica, R. maracandica, Elytrigia trichophora, Origanum tytthantum, Ferula kuhistanica, Perovskia scrophularifolia, Achillea millefolium) 8 - $9 \mathrm{~km}$ south of Tamshush (Gisar's plane; above sea level). The area is $20 \times 20 \mathrm{~m}$; the soil is dark gray; there are small fertilizers on the surface. Vegetation covers $65 \%$ - 70\%. Rosa kokanica $R$. maracandica copil are abundant at the height of 1.5 - $2 \mathrm{~m}$; Subradiator Cerasus erythrocarpa, Lonicera nummulariifolia, $\mathrm{Sp}^{2}$, height $1.5 \mathrm{~m}$; abundance of oregano and couch grass $\mathrm{Sp}^{1}-\mathrm{Sp}^{2}$, height $40-50 \mathrm{~cm}$ (second tier). Ferula kuhistanica, Perovskia scrophularifolia, Achillea millefolium, $\mathrm{Sp}^{1}$ are also involved. They, too, on the 2 nd tier and on the lower tier there are grass, bluegrass, silverweed, $20-25 \mathrm{~cm}$ high.

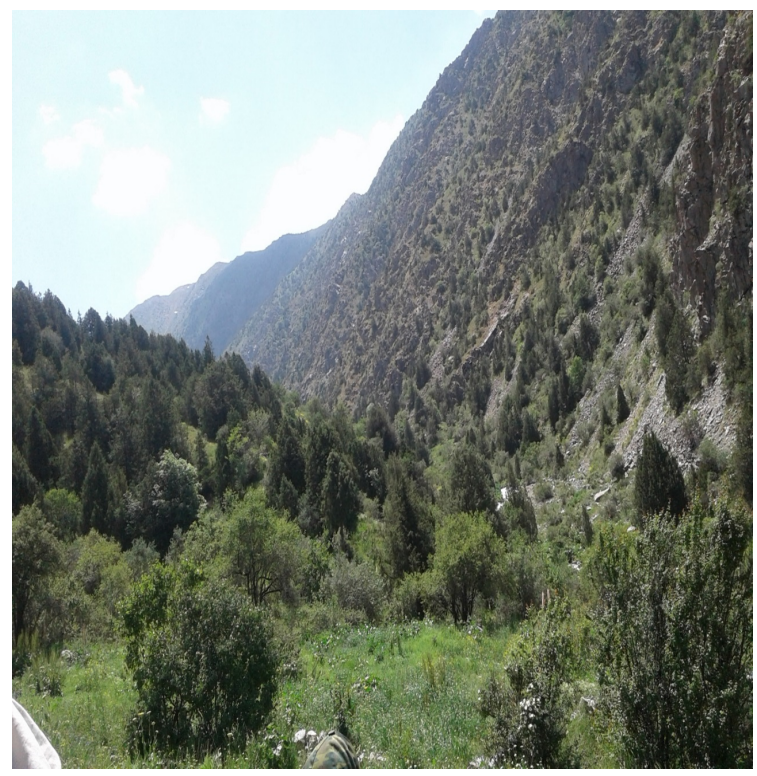

Figure 1. Plant communities of Juniperus (Gissar reserve). 
10) Rosa kokanica, R. maracandica, Origanum tytthanthum, Ferula kuhistanica, Perovskia scrophularifolia, Achillea millifolium Elytrigia trichophora, Poa bulbosa), area $20 \times 20 \mathrm{~m}$ gray, in some places brown soil with dark brown and stony rocks. The community is Rosa maracandica, $R$. kokanica cop ${ }^{1}$ abundance, height $1.5 \mathrm{~m}$. Subradifier Cerasus erythrocarpa abundance of $\mathrm{Sp}^{2}$, height $1.0 \mathrm{~m}$. And in the first tier Etytrigia trichophora, Origanum tytthanthum, abundance of $\mathrm{Sp}^{2}$, Poa bulbosa, Phleum phleoides, Bromus macrostachys, abundance of $\mathrm{Sp}^{1}$ Height $30-40 \mathrm{~cm}$. They are evenly distributed in the community, followed by Ferula kuhistanica, Perovskia scrophularifolia, Achillea millifolium, Cousinia microcarpa.

11) Rosa kokanica, R. maracandica, $R$. nanothamnus, Origanum tythanthum, Elytrigia trichophora. $20 \mathrm{~km}$ from the village of Suvlisay (Yakkabag), this association is located at an altitude of $1900-2000 \mathrm{~m}$ above sea level. $\mathrm{m}$ on the eastern slope. The soil is light brown, fine, soft, and some places are covered with stony rocks. Vegetation cover is 55\%. Rosa kokanica is abundant in Cop ${ }^{2}$, Rosa maracandica, $\mathrm{Cop}^{1}$, R. ecae, $\mathrm{Sp}^{2}$, height $1.0-1.5 \mathrm{~m}$. All three species of wild rose grow evenly over an area of $20 \times 20 \mathrm{~m}$ : Rosa canina subedifier abundance of $\mathrm{Sp}^{2}$, height 1 - 1.5 m. Rosa fedtchenkoana, abundance of Sp1, in addition, Cerasus erythrocarpa, Cotoneaster songorica, Lonicera nummulariifolia, Berberis oblonga, Prunus divaricata, Amygdalus spinosissima (for the first time). In the second tier $(40-50 \mathrm{~cm})$, cereals, astragalus (covered with stone bark) $\mathrm{Sp}^{2}$, Bromus danthonia and B. macrostachys were found in abundance of $\mathrm{Sp}^{2} 3$ tier $(25-30 \mathrm{~cm})$. There are many shrubs and other plants in this community. Almonds are planted on the terraces-5 - 8 summer trees. The area is in good condition. Therefore, there are many species of wild rose and other shrubs here.

Cenotype: Juniperus-Arceuthodendra;

Formation: Zarafshan Archa-Junipereta sarawschanicae.

Juniperus sarawschanica is a Zeravshan juniper of the Juniperus family (juniper). This species of juniper is found in the studied areas at an altitude of 2000 $2500 \mathrm{~m}$, in mountain slopes.

\section{Associations:}

12) Juniperus sarawschanica, Elytrigia trichophora. This association occurs at an altitude above $2000 \mathrm{~m}$ above sea level in the areas studied by us. Brown soils on the slopes, on the surface of rubble, on the slopes on brown soils there are shrubs up to $1 \mathrm{~m}$ high. In this association, the edifier is Juniperus sarawschanica, abundance, $\mathrm{Sp}^{3}$, density 0.3 - 0.4, height 4 - $5 \mathrm{~m}$, subedifier Elytrigia trichophora, 40 - $50 \mathrm{~cm}$ high in $\mathrm{Cop}^{1}$, members of this community Rosa maracandica, Lonicera nummulariifolia, Poa angustifolia, Artemisia tenuisecta, Perovskia scrophularifolia, Cousinia microcarpa, Hordeum bulbosum and many others, Poa bulbosa- $\mathrm{Sp}^{1}$. In the community, vegetation cover covers $40 \%-60 \%$ (excluding juniper). 
13) Forbs-Pirein-Zarafshan juniperus (Juniperus sarawschanica, Elytrigia trichophora, Poa bulbosa, Phlomis thapsoides, Centaurea squarrosa), is similar to the above association, but the majority of the vegetation falls on the wheatgrass-Cop ${ }^{1}$, Poa bulbosa $S p^{1}$, aphorus, Cop, Poa bulbosa $S p^{1}$, the crop association, but the majority of the vegetation falls on the wheatgrass-Cop ${ }^{1}$, Poa bulbosa $S p^{1}$, the crop association, Copyra, Poa bulbosa $\mathrm{Sp}^{1}$, the share of the above mentioned association, but the majority of the vegetation accounts for the wheatgrass. Grass covers $60 \%-80 \%$. Unlike the previous community, the grass is $20 \%$ more abundant, and the trees of Juniperus sarawschanica are higher and reach a height of $2-3 \mathrm{~m}$. Subaeditor Poa bulbosa and forbs. Obviously, the location on the northern slopes has an impact on the development of this association.

14) Mint-wormwood-shrub-zarafshan juniper (Juniperus sarawschanica, Rosa maracandica, $R$. kokanica, $R$. hissarica, Lonicera altmanii, Artemisia tenuisecta, Poa bulbosa, P. angustifolia, Elytrigia trichorahorachera, Elythriia trichorahotecta, from the village of Suvlisay and covers an area of $20 \times 20 \mathrm{~m}$, the soil is brown, in some places the stones are washed out. Herbal cover of plants is $60 \%$. Edificator of juniper zarafshanskaya, $\operatorname{Cop}^{1}$ abundance, density 0.5 , bonitet 4 , height 5 - 6 m. Subedifiers Rosa canina, R. maracandica, R. hissarica, Lonicera altmannii $\mathrm{Sp}^{3}$, Artemisia tenuisecta $\mathrm{Sp}^{1}$ (Figure 2).

15) Forbs-shrubs-juntaus sarawschanica, (Juniperus sarawschanica, Rosa fedtschenkoana, R. hissarica, $R$. maracandica, Lonicera sarawschanica, Phlomis olgae, Eremurus regelii). It is widespread in the Suvlisay Valley and in the Gissar Reserve. The soil is brown, soft, finely gravelly cartilaginous. Grass cover in association is $60 \%-70 \%$. Juniperus sarawschanica edificator, Cop ${ }^{1}-$ Cop $^{2}$ abundance, density $0.5-0.6$, height $6-8 \mathrm{~m}$, rarer also Acer pubescens $(5-6 \mathrm{~m})$ and Prunus divaricata (5 m), Sol abundance. Barberry ordinary, Rosa kokanica, $R$. maracandica are $1.5-2 \mathrm{~m}$ high. $R$. hissarica, $R$. fedtschenkoana, and others, whose number $\mathrm{Sp}^{1}$, grass cover is $65 \%-70 \%$.

16) Juniperus sarawschanica, Rosa hissarica, $R$. maracandica, Lonicera sarawschanica, Elytrigia trichophora, in Yakkabag forestry distributed. The soil is dark brown, edificator archa zarafshan abundance of $\mathrm{Sp}^{3}$, height $5-6 \mathrm{~m}$. The second tier is similar to the composition of the association 15 , but the plants are rare.

17) Juniperus sarawschanica, Ziziphora pamiroalaica, Poa bulbosa, Elytrigia trichophora.

These 3 associations we noted in department Yakkabag forestry No. 1 at altitudes of $1800-2000 \mathrm{~m}$ asl. The area is covered with brown soils. In some places the stones lie on the ground. The edificator is the archa zarafshanskaya, the abundance of $\mathrm{Sp}^{3}$, the density is $0.3-0.4$, the height is $5-6 \mathrm{~m}$. The wheatgrass $\mathrm{Sp}^{1}$, bluegrass abundant $\mathrm{Sp}^{3}$, Astragalus bactrianus $\mathrm{Sp}^{1}$, Cousinia microcarpa Sol, Plantago lanceolata Sol and others grow in the second tier with less common shrubs. 


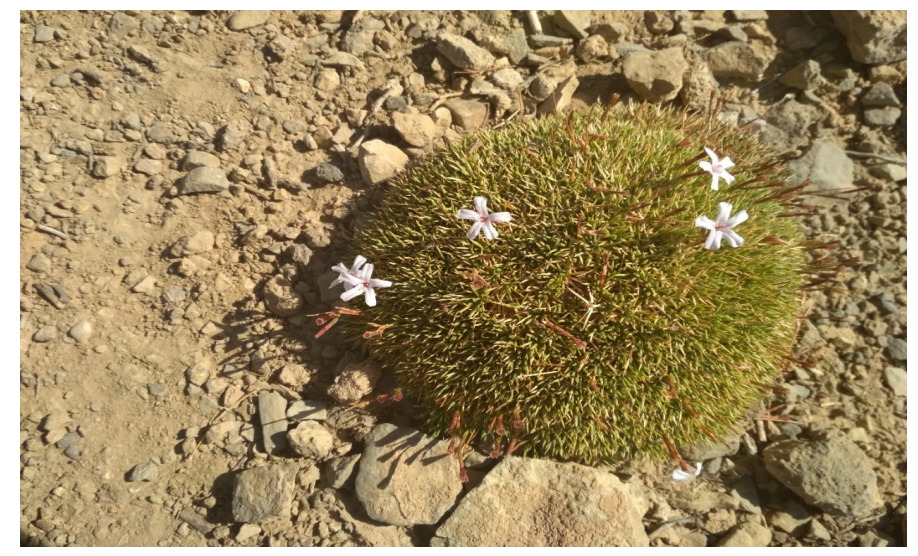

Figure 2. Acantholimon butkovii ( Suvlisay).

Formation: Hemispheric Juniper-Junipereta semiglobosae.

20) Juniperus semiglobosa, J. sarawschanica, Festuca valesiaca, Elytrigia trichophora, $15 \mathrm{~km}$ south of the village of Tamshushsay. The area is $20 \times 20 \mathrm{~m}$, the soil is typical, brown, in places small jackdaws. The edificator is Juniperus semiglobosa, Cop1 abundance, height $8-9 \mathrm{~m}$, density 0.5. Juniperus sarawschanica subedificator, abundance of Sp2, density 0.4, height $6-7 \mathrm{~m}$. Herbs are Elytrigia trichophora $\mathrm{Cop}^{3}-\mathrm{Cop}^{1}, \mathrm{Sp}^{2}$ bluegrass, $\mathrm{Sp}^{1}$ fire, and shrubs are less common.

\section{Associations:}

21) Juniperus semiglobosa, J. sarawschanica, Festuca valesiaca, Elytrigia trichophora, Cousinia umbrosa, Potentilla asiatica, Scabiosa chirophiothora $15 \mathrm{~km}$ south of the village Tamshush. The area is $20 \times 20 \mathrm{~m}$, the soil is typical, brown, small, in places small jackdaws. The edificator is Juniperus semiglobosa, Cop ${ }^{1}$ abundance, height $8-9 \mathrm{~m}$, density 0.5 . Juniperus sarawschanica subedificator, abundance of $\mathrm{Sp}^{2}$, density 0.4 , height $6-7 \mathrm{~m}$. Herbs are Elytrigia trichophora $\mathrm{Cop}^{3}-\mathrm{Cop}^{1}, \mathrm{Sp}^{2}$ bluegrass, $\mathrm{Sp}^{1}$ fire, and shrubs are less common.

22) Forbs-bluegrass-fescue-zarafshan's junipers-hemispherical junipers (Juniperus semiglobosa, J. sarawschanica, Festuca valesiaca, Poa bulbosa, P. angustifolia, Bromus paulsenii, Arenaria griffithii, Allium chashes, and a few-fourfour-five-a-year-olds) south of the Suvlisay. Area $20 \times 20 \mathrm{~m}$, typical brown soils are well pronounced. In the community, the Juniperus semiglobosa Cop $^{2}$ edificator has a density of 0.4 , a bonitet IV, a height of $7 \mathrm{~m}$. A subdued Juniperus sarawschanica, a Cop ${ }^{1}$ strength, a density of 0.6 , a bonitet 4 , a height of $7 \mathrm{~m}$. The grass cover is $70 \%$. Festuca valesiaca with abundance of $\mathrm{Cop}^{1}$, bluegrass Sp1, wheat grass $\mathrm{Sp}^{1}$, Poa angustifolium $\mathrm{Sp}^{1}$, Hordeum brevisubulatum $\mathrm{Sp}^{1}$. From mixed grass Geranium collinum $\mathrm{Sp}^{1}$, Convolvulus lineatus Sol, Bromus macrostachys Sol, Galium pamiralaicum Sol.

23) Juniperus semiglobosa, J. sarawschanica, Festuca valesiaca, Geranium collinum, Plantago lanceolata), Area $20 \times 20 \mathrm{~m}$. Small brown soil. In the vegetation cover of this association, two junipers are edificators growing on the 1st tier, 4 $5 \mathrm{~m}$ high. Abundance-Cop ${ }^{1}$, density 0.5 , bonitet IV. Herbal coverage is 55\% - 
60\%. The dominant is Festuca valesiaca, the abundance of its $\mathrm{Sp}^{3}$, wheat grass and bluegrass are subdominant, the abundance of $\mathrm{Sp}^{2}$. Of mixed herbs found in Convolvulus lineatus, Plantago lanceolata Sol.

Highland plants:

Type: Highland plants-Ipsilioreophyton;

Subtype: subalpine-Ipsilorimesophyta;

Coenotype: nasnokserofitnye meadows-Cryofriganopoia;

Formation: Kuzinia whorled-Cousinieta verticillaris.

\section{Associations:}

We met 20 - $25 \mathrm{~km}$ from the village of Suvlisai of the Yakkabag forestry at an altitude of 2900 - $3000 \mathrm{~m}$ above sea level. m. 24. Akantolimonovo-feschakovocousine (Cousinia verticillaris, Festuca valesiaca, Acantholimon butkovii), 25) Wormwood-acantholimone-cusine (Cousinia verticillaris, Acantholimon butkovii, Artemisia lehmanniana). The edifier of Cousinia verticillaris by the abundance of $\mathrm{Cop}^{1}$, the subedificator Acantholimon butkovii $\mathrm{Sp}^{2}$, A. erythraeum Sol. The participant of these associations is, Cerasus erytrhrocarpa Sol, Convolvulus lineatus Sol, less common is the juniper spawning Sol, Juniperus semiglobosa Sol, the plant cover of herbs is $50 \%$.

Subtype: Highland freegans-Cryofriganophyta;

Coenotype: Kolyuchepodushechniki-Cryotapeta;

Formation: Acantolimone-Acantholimoneta butkovi.

\section{Associations:}

26) Acantholimon butkovii, Festuca valesiaca, Cousinia verticillaris

27) Acantholimon butkovii, Cousinia verticillaris, Carex stenophylloides). These associations occurred at $3000-3200 \mathrm{~m}$ above sea level. The soil is rocky, fine and gravelly.

In these acatnolimonics, the edificator is the Acantholimon butkovii-Cop ${ }^{2}$. Subedifiers-Festuca valesiaca, $\mathrm{Sp}^{3}-\mathrm{Sp}^{2}$. Cousinia verticillaris $\mathrm{Sp}^{3}$ Artemisia lehmanniana Sol, Acanthophylum sp. Sol. Vegetation cover is $40 \%$.

\section{Conclusions}

During the expeditions, more than 110 herbarium leaves were collected in the surveyed territories and plant species were identified.

In conclusion, the region is currently under intense anthropogenic and manmade impact. The increasing impact on vegetation has caused significant changes in the composition and structure of communities in different zones of the foothill and mountainous areas. As a result, the diversity of vegetation and plant communities has decreased; their productivity and renewable capacity have decreased.

\section{Conflicts of Interest}

The author declares no conflicts of interest regarding the publication of this paper. 


\section{References}

[1] Field Geobotany. (1959-1976): 1-5. Nauka, Moscow-Leningrad, 3-500.

[2] Vegetation Cover of Uzbekistan. In 4 tons. Tashkent, 1984. T 4, 86-347. https://www.britannica.com/place/Uzbekistan

[3] Zakirov, P.K. (1989) Classification of Vegetation in Central Asia. Uzbek Biological Journal, 3, 43-50.

[4] Zakirov, K.Z. and Zakirov, P.K. (1978) Experience in the Typology of the Vegetation of the Globe on the Example of Central Asia. Fan, Tashkent, 56 p.

[5] Zakirov, K.Z. and Zakirov, P.K. (1969) Principles and Nomenclature of Vegetation Typology. Uzbek Biological Journal, 5, 34-41. 